\title{
REVISED GUIDELINES FOR DIAGNOSIS OF PERINATAL HIV-1 INFECTION IN SOUTH AFRICA
}

\author{
W Stevens, $M B$ BCh, MMed (Haem), FCPath (Haem) \\ G Sherman, $M B B C h, D C H(S A), D T M \& H, M M e d$ (Haem) \\ Department of Molecular Medicine and Haematology, University of the Witwatersrand, fohnnesburg, and National Health Laboratory Services, \\ South Africa
}

M Cotton, $M B C h B$, FCPaed (SA), MMed (Paed), PhD, DTM\&H, DCH (SA)

Department of Paediatrics and Child Health, Stellenbosch University, Tygerberg, W Cape

\section{Gerntholtz}

AIDS Law Project, Centre for Applied Legal Studies, University of the Witwatersrand, Fohannesburg

L Webber, MB ChB, MMedPath (Virol), DTH

Lancet Laboratories, fohannesburg

These guidelines for best practice under both ideal and resource-constrained conditions are intended to provide guidance for health care professionals regarding the laboratory diagnosis of HIV-1-infected infants and young children. Resources, circumstances and decisions will differ across the wide range of clinical settings occurring in southern Africa and other developing countries. These serve as an update of guidelines published in this journal in $2001 .^{1}$

The diagnosis of HIV-1 infection in infants begins with identifying HIV-1 infection in women before and during every pregnancy; this awareness should also identify the infant at risk for HIV-1 infection. ${ }^{2,3}$ Nonetheless, perinatal HIV-1 diagnosis presents challenges such as:

Difficulty in establishing an early and rapid diagnosis in exposed infants due to the persistence of transplacentally acquired maternal IgG HIV-1 antibodies. These may remain present in the blood for $15-18$ months. ${ }^{4}$

- Timing of HIV-1 transmission from mother to child, which directly affects the sensitivity and specificity of available HIV-1 diagnostic assays.

- The risk of the infant being exposed to HIV-1 throughout the duration of breastfeeding.

Whether to use quantitative and/or qualitative HIV-1 nucleic acid-based virological assays.

- The utility and role of detecting p24 antigen for diagnosis and prognosis.

- The global existence of multiple clades or subtypes of HIV1 and its effect on assay performance. ${ }^{5-10}$

Clinical acumen should prevail in interpreting HIV-1 test results; for example, HIV-1 infection can be ruled out in children $\geq 18$ months of age with negative HIV-1 serology, a history of either no breastfeeding or breastfeeding that ceased at least 6 weeks previously, no clinical symptoms of HIV-1 disease and no hypogammaglobulinaemia. ${ }^{4}$ Rapid HIV tests should perform as well in children $>18$ months as in adults. Algorithms are in the process of being validated locally.

In turn, all women should be encouraged to undergo voluntary counselling and testing (VCT). ${ }^{2}$ As per National Treatment guidelines for infants, ${ }_{1}^{11}$ testing may only be conducted on infants following pre-test counselling and only once informed consent has been obtained from parents, legal guardians or primary caregivers. This document should be read in conjunction with the testing algorithm summarised in Fig. 1.

\section{INTRODUCTION}

The need for expanded testing practices for the early diagnosis of HIV in exposed infants is now well established, hence the urgent need for review of these infant diagnostic guidelines. Early diagnosis is critical to facilitate:

comprehensive care of infected children including ARV treatment

avaluation of prevention of mother-to-child transmission (PMTCT) programmes, and

added social benefits such as a reduction in maternal anxiety, $^{12}$ stratification of health care services, and recommendations for appropriate infant feeding practices.

HIV-infected children under 24 months of age are a particularly vulnerable group. A recent natural history study showed that approximately 35\% of infected children in Africa died before 1 year of age and that more than 52\% have died by their 2 nd birthday. ${ }^{13}$ Early diagnosis has the potential to reverse this situation, provided that primary care services are adequately capacitated to provide these children with appropriate care including nutritional support, co-trimoxazole prophylaxis, clinical and CD4 count monitoring and timely referral for antiretroviral therapy. 


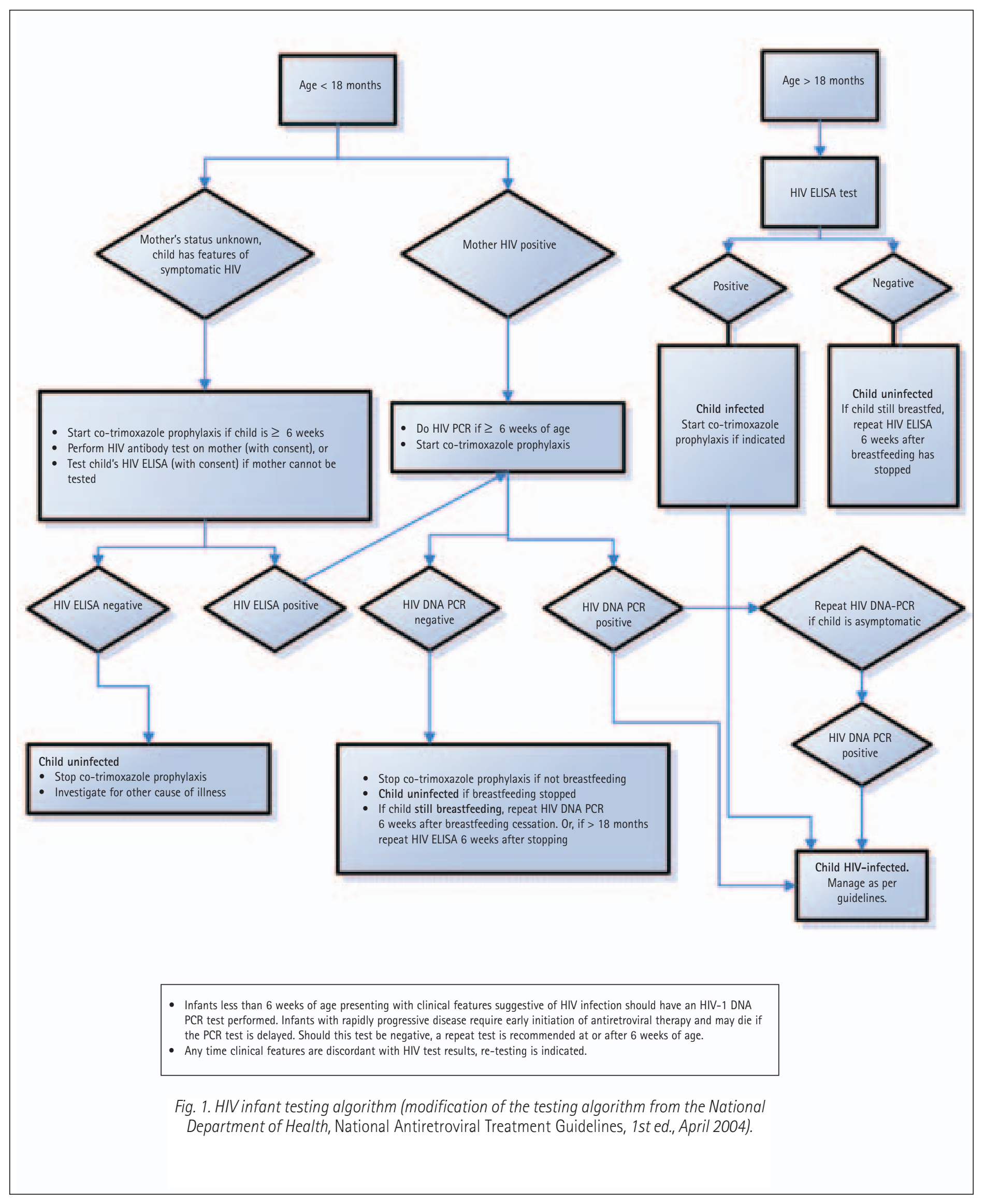


Based on recent antenatal HIV prevalence figures of 29.5\% ${ }^{14}$ and assuming there are a million births per year in South Africa, approximately 300000 infants require access to early diagnosis. Previously, protocols in resource-poor settings have recommended that infants be followed up for 1 year on cotrimoxazole prophylaxis from 6 weeks of age and then tested using HIV enzyme-linked immunosorbent assay (ELISA) testing strategies at 12 months of age. The reality of this practice is illustrated by experience in Johannesburg, South Africa, where over $60 \%$ of infants were lost to follow-up by 6 weeks and $85 \%$ by 12 months of age during a 24-month period (October 2001 - September 2003)..$^{15,16}$ The absence of a diagnosis, and the death of $40 \%$ of HIV-infected infants by 12 months of age, severely limits children's access to comprehensive care. ${ }^{17}$ Furthermore, a diagnostic algorithm incorporating a single HIV DNA polymerase chain reaction (PCR) test at 6 weeks of age costs society less than one that uses an HIV ELISA test at 12 months of age. ${ }^{18}$

Much emphasis has been focused on choosing the appropriate technology to allow for timeous diagnosis. Important considerations include:

a sample volume

mode of specimen collection

required turnaround

laboratory technical skills, and

cost.

Recent work in Johannesburg has confirmed the potential value of two diagnostic assays for early infant diagnosis of HIV:

Roche HIV DNA PCR assay version 1.5, and

a the ultrasensitive heat-denatured p24 antigen quantitation assay. ${ }^{19}$

In summary, 627 non-breastfed HIV-exposed infants (58 HIV positive) had their HIV status determined according to Centers for Disease Control (CDC) guidelines. A single HIV DNA PCR using the Roche Amplicor assay version 1.5 at 6 weeks of age had a sensitivity of $98.8 \%$ and specificity of $99.4 \% .{ }^{20}$ The use of the 6-week visit coincides with the first immunisation visit and thus fits in well with the continuum of care.

The performance of the Roche HIV DNA PCR assay has been confirmed in other regions as summarised in Table I.

Data on the second option, the ultrasensitive heat-denatured p24 antigen assay at 6 weeks, yielded satisfactory results in

TABLE I. SUMMARY OF PERFORMANCE OF ROCHE AMPLICOR HIV DNA PCR ASSAY VERSION 1.5 IN DIFFERENT SUBTYPES
TABLE II. SUMMARY OF PERFORMANCE OF ULTRASENSITIVE HEAT-DENATURED P24 ANTIGEN QUANTITATION ASSAY FOR INFANT DIAGNOSIS OF HIV

\begin{tabular}{|lcll|}
\hline Region & $\begin{array}{c}\text { Prevalent } \\
\text { subtype }\end{array}$ & $\begin{array}{l}\text { Sensitivity } \\
\text { and specificity }\end{array}$ & Reference \\
\hline Tanzania & A, D & $99 \%, 100 \%$ & Lyamuya et al. ${ }^{26}$ \\
Switzerland; & B & $97-98 \%$ sensivityl & Nadal et al. ${ }^{27}$ \\
US & & $98-99 \%$ specificity & Respess et al. ${ }^{28}$ \\
Thailand and & E & $97-98 \%$ sensitivityl & Sutthent et $a l_{.1}{ }^{29}$ \\
Cambodia & & $97-99 \%$ specificity & Nouhin et al. ${ }^{30}$ \\
& & &
\end{tabular}

South Africa with a sensitivity and specificity of $97.7 \%$ and 100\% respectively when compared with HIV DNA PCR testing. ${ }^{25}$ The performance of this assay for infant diagnosis has been confirmed in other studies and is summarised in Table II.

In remote settings, difficulties have been experienced with sample collection and transport for infant diagnostic specimens. This has been overcome with the use of dried blood spots followed by extraction and the Roche HIV DNA PCR assay. The Roche HIV DNA version 1.5 PCR assay performed on unmodified filter paper at 6 weeks of age yielded an accurate diagnosis of HIV infection with a sensitivity and specificity of 100\% and 99.6\% respectively compared with PCR conducted on whole-blood samples. ${ }^{31}$ Preliminary data suggest that DBS from capillary (e.g. heel prick) versus venous blood also yields highly accurate HIV DNA PCR results (personal communication - G Sherman). The ultrasensitive p24 ag assay has recently been modified for use on dried plasma ${ }^{32}$ and dried blood spots. $^{33}$

In the South African context, owing to the sheer numbers of samples needing diagnosis, automated testing methodologies for assays such as the Roche HIV DNA PCR assay have been explored. To date the automation of the extraction method for this assay has been optimised using the Roche MagNapure Analyser. When comparing this approach with the conventional whole-blood manual extraction method 100\% concordance was noted (W Stevens - personal communication). This method also reduced the number of equivocal results and internal control failures to $1-2 \%$ of samples run. Preliminary data suggest that this method works well for dried blood spots using the MagNapure LC DNA Isolation kit III (W Stevens - personal communication) and the data will be published shortly.

\section{DEFINITION OF AN HIV-1-UNINFECTED INFANT/CHILD}

A child should not be labelled as HIV positive simply if the mother is HIV positive; the correct terminology in this situation is HIV-exposed.

An HIV-1-uninfected infant/child can be defined as an infant/ child with a negative HIV-1 serological or virological test 
where clinical features are not discordant. The following modifiers apply to age categories:

- For children older than 18 months of age a negative HIV1 serological test based on the ELISA method confirms absence of HIV-1 infection, provided that breastfeeding ceased at least 6 weeks before the first test.

For infants between 6 weeks and 18 months of age, one negative HIV DNA PCR test result indicates non-infection provided that breastfeeding ceased at least 6 weeks before the test. Confirmation of an infant's HIV infection status using an HIV ELISA test at 15 - 18 months can be done.

\section{DEFINITION OF AN HIV-1-INFECTED INFANT/CHILD AND RECOMMENDATIONS ON THE USE OF HIV TESTS}

HIV-1 diagnostic techniques are more difficult to interpret in infants and young children than in older children or adults because of the persistence of maternal antibodies up to 12 - 18 months of age. The HIV-1 DNA PCR detects the integrated HIV virus DNA ('provirus') into the genome of mononuclear cells, and is considered the test of choice for establishing the diagnosis of perinatally acquired HIV-1 infection. ${ }^{34}$ This PCR is a diagnostic qualitative reaction, distinct from the RNA quantitative reaction (viral load test) used for the prognostic staging or clinical monitoring. ${ }^{35}$ The HIV-1 DNA PCR is a rapid and accurate method for identification of HIV-1 infection in infants and young children under 18 months of age. Currently the only assay with extensive validation in South Africa is the Roche Amplicor DNA assay version 1.5. However, PCR amplification is prone to contamination and testing should take place strictly according to the manufacturer's instructions and only in areas dedicated for PCR work. HIV-1 DNA PCR methods are considered reliable when standardised and performed in laboratories following good laboratory practices.

These tests have been accurate for all known HIV-1 subtypes but ongoing molecular surveillance is necessary to confirm their performance for novel subtypes.

- An HIV-1 DNA PCR test should be performed on infants between 6 weeks and 18 months of age for diagnosis. If the HIV-1 DNA PCR is positive infection is established, and if the infant is currently being breastfed this may be continued and the infant should receive prophylaxis for opportunistic infections such as Pneumocystis jiroveci.

- Infants under 6 weeks of age presenting with clinical features suggestive of HIV infection should have an HIV-1 DNA PCR test performed. Infants with rapidly progressive disease require early initiation of antiretroviral therapy and may die if the PCR test is delayed. Should this test be negative, a repeat test is recommended at or after 6 weeks of age

- In infants over 18 months of age, a positive HIV ELISA assay as per the national testing algorithm confirms diagnosis of HIV infection.
Whenever clinical features are discordant with HIV test results, re-testing is indicated.

\section{DETERMINATION OF HIV INFECTION IN ABANDONED/ORPHANED INFANTS}

- Perform an HIV ELISA to assess HIV exposure at birth if results for the mother are not available. If you have confirmation of a positive HIV ELISA result for the mother this test may be omitted.

- If HIV antibody assay for mother or infant is positive, perform an HIV DNA PCR assay at 6 weeks. This may be repeated on a second sample at any stage to confirm the 6-week result and comply with the HIV testing requirements of adoption agencies.

\section{LEGISLATION REGARDING HIV TESTING IN INFANTS}

The final version of the Bill is not yet available but will be shortly and posted at http://www.gov.za and called the Children's Act. In summary, the following important information will be included:

- Informed consent to HIV testing may be obtained from a child aged 12 years or older without the assistance of the parents/caregivers provided the child is sufficiently mature to understand the implications of the test. If the child is under 12 years of age but is sufficiently mature to understand the implications of the test, consent may be obtained without the assistance of parents/caregivers.

- If the child is under 12 years of age and cannot understand the implications of the test, and has no parents and caregivers, consent is to be obtained from the provincial head of social development.

- If the child is under 12 years of age and not mature, options are as follows:

- the child protection agency arranging the placement of the child can consent, or

- the medical superintendent/person in charge of the hospital - if no parents/caregiver and no child protection agency is involved, or

- the children's court - if consent is being withheld (by anyone capable of giving consent, not just parents) or if child and parents are not able to give consent.

- In the case of an abandoned child who has obviously been deserted by parent/s, legal guardian or caregiver or who has had no contact with parent/s, legal guardian or caregiver for 3 months for no apparent reason, a caregiver may give consent. A caregiver is defined as the individual who actually cares for a child and may include a foster parent, kinship carer, person who cares for a child in temporary safe care, head of shelter, child protection or youth agency, child or youth care worker who cares for a child without appropriate care in the community, and child who is head of a child-headed household.

- Consent to HIV testing also cannot be withheld unreasonably.

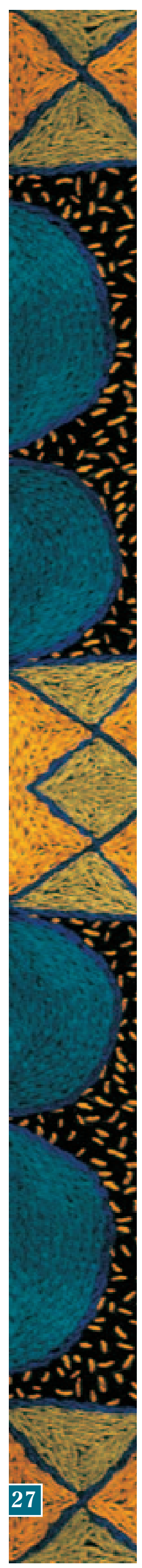




\section{OTHER POINTS TO CONSIDER}

In South Africa, the quantitative HIV RNA (viral load) test has not been validated as a diagnostic tool but should be reserved for assessing prognosis and further management of the patient. The reasons for this recommendation include the following:

- workflow issues within local laboratories, and

- delayed transport from remote areas causing deterioration of RNA.

The measurement of HIV-1 p24 antigen in blood is sensitive enough for early diagnosis of HIV infection in infants and young children only if the ultrasensitive heatdenatured p24 antigen quantitation assay described by Schupbach and colleagues. (Ledergerber et al. ${ }^{19}$ ) is used. Until a consistent reagent and buffer for this assay have been obtained, it should not be widely used.

- Whether to test all infants at 6 weeks of age or delay testing in breastfed infants until 6 weeks after breastfeeding has ceased, remains controversial.

- The current national diagnostic algorithm recommends antibody tests after 18 months of age despite the fact that many uninfected infants serorevert (lose maternal HIV antibodies) between 9 and 12 months of age. It is reasonable to use HIV antibody tests earlier than 18 months of age provided health care workers understand that a positive HIV ELISA test under 18 months of age may indicate HIV exposure and not HIV infection.

REFERENCES

1. Weber LM, Cotton M, Stevens W. Diagnosis of perinatal HIV- 1 infection in South Africa. Southern African Journal of HIV Medicine 2001; issue 5, 21-26.

2. Gray GE, McIntyre JA, Jivkov B, Violari A. Preventing mother-to-child transmission of HIV-1 in South Africa; recommendations for best practice. Southern African Journal of HIV Medicine 2001; issue 4, 15-26.

3. Davis SF, Byers RH jun, et al. Prevalence and incidence of vertically acquired HIV infection in the United States. JAMA 1995; 274: 952-955.

4. Nielsen K, Bryson YJ. HIV/AIDS in infants, children and adolescents. Paediatr Clin North Am 2000; 47 (1): 39-58.

5. Dickover $R$, Dillon $M$, Leung $K M$, et al. Early prognostic indicators in primary perinatal HIV-1 infection: importance of viral RNA and the timing of transmission on long-term outcome. J Infect Dis 1998; 178: 375-387.

6. Dunn DT, Newell ML, Ades AE, Peckham CS. Risk of human immunodeficiency virus type 1 transmission through breastfeeding. Lancet 1992; 340: 585-588.

7. Ekpini ER, Wiktor SZ, Satten GA, et al. Late postnatal mother-to-child transmission of HIV-1in Abidjan, Cote d'Ivoire. Lancet 1997; 349: 1054-1059.

8. Palumbo PE, Kwok S, Waters $S$, et al. Viral measurement by polymerase chain reaction-based assays in human immunodeficiency virus-infected infants. J Pediatr 1995; 126: 592-595.

9. Martin D, Sim J. The laboratory diagnosis of HIV infection. S Afr J Med 2000; 90: 105-109.

10. Daar ES, Little S, Pitt J, et al. Diagnosis of primary HIV infection. Ann Intern Med 2001; 134: 25-29.

11. National Department of Health. National Antiretroviral Treatment Guidelines. 1st ed., April 2004. http://www.doh.gov.za/docs/factsheets/guidelines/ artguide04-f.html (last accessed 23 February 2006).

12. Varga, CA, Sherman GG, Maphosa J, Jones SA. Psychosocial consequences of early diagnosis of HIV status in vertically exposed infants in Johannesburg, South Africa. Health Care Women Int 2005; 26(5): 387-397.

13. Newell ML, Coovadia H, Cortina-Borja M, Rollins N, Gaillard P, Dabis F; Ghent International AIDS Society (IAS) Working Group on HIV Infection in Women and
Children. Mortality of infected and uninfected infants born to HIV-infected mothers in Africa: a pooled analysis. Lancet 2004; 364(1): 1236-1243.

14. Department of Health, 2005. National HIV and Syphilis Antenatal Seroprevalence Survey in South Africa 2004. www.doh.gov.za/docs/reports/2004/ hiv-syphilis.pdf (last accessed 23 February 2006).

15. Sherman $G G$, Jones $S A$, Coovadia AH, Urban MF, Bolton KD. PMTCT from research to reality - results from a routine service. S Afr Med J 2004; 94: 289292.

16. Jones $S A$, Sherman GG, Varga CA. Exploring socio-economic conditions and poor follow-up rates of HIV-exposed infants in Johannesburg, South Africa. AIDS Care 2005; $17(4)$ : 466-470.

17. Jones SA, Sherman GG, Coovadia AH. Can clinical algorithms deliver an accurate diagnosis of HIV infection in infancy? Bull World Health Organ 2005; 83(7): 559-560.

18. Sherman GG, Matsebula TC, Jones SA. Is early HIV testing of infants in poorly resourced prevention of mother to child transmission programmes unaffordable? Trop Med Int Health 2005; 10: 1108-1113.

19. Ledergerber B, Flepp M, Boni J, et al. HIV-1 p24 concentration measured by boosted ELISA of heat-denatured plasma correlates with decline in CD4 cells, progression to AIDS, and survival: comparison with viral RNA measurement. $J$ Infect Dis 2000; 181: 1280-1288.

20. Sherman GG, Cooper PA, Coovadia AH, et al. Polymerase chain reaction for diagnosis of HIV infection in infancy in low resource settings. Pediatr Infect Dis J 2006; 24: 993-997.

21. Zijenah LS, Humphrey J, Nathoo K, et al. Evaluation of the prototype Roche DNA amplification kit incorporating the new SSK145 and SKCC1B primers in detection of human immunodeficiency virus type 1 DNA in Zimbabwe. J Clin Microbiol 1999; 37(11): 3569-3571.

22. Lyamuya $E_{1}$ Olausson-Hansson $E_{1}$ Albert J, Mhalu F, Biberfeld G. Evaluation of a prototype Amplicor PCR assay for detection of human immunodeficiency virus type 1 DNA in blood samples from Tanzanian adults infected with HIV-1 subtypes A, C and D. J Clin Virol 2000; 17(1): 57-63.

23. Fischer A, Lejczak C, Lambert C, et al. Simple DNA extraction method for dried blood spots and comparison of two PCR assays for diagnosis of vertical human immunodeficiency virus type 1 transmission in Rwanda. J Clin Microbio/ 2004; 42(1): 16-20.

24. Sherman GG, Stevens WS, Stevens G, Galpin JS. Diagnosis of human immunodeficiency virus infection in perinatally exposed orphaned infants in a resource poor setting. Pediatr Infect Dis J 2000: 19: 1014-1015.

25. Sherman G, Stevens G, Stevens W. Affordable diagnosis of human immunodeficiency virus infection by $\mathrm{p} 24$ antigen detection. J Pediatr Infect Dis 2004; 23: 173-176.

26. Lyamuya $E$, Bredberg-Raden U, Massawe A, et al. Performance of a modified HIV-1 p24 antigen assay for early diagnosis of HIV-1 infection in infants and prediction of mother-to-infant transmission of HIV-1 in Dar es Salaam, Tanzania. JAIDS 1996; 12: 421-426.

27. Nadal D, Boni J, Kind C, et al. Prospective evaluation of amplification-boosted ELISA for heat-denatured p24 antigen for diagnosis and monitoring of pediatric HIV-1 infections. J Infect Dis 1999; 180: 1089-1095.

28. Respess $R$, Cachafeiro A, Fiscus $S$, et al. Evaluation of a commercially available ultrasensitive p24 antigen (UPTA) viral load assay in samples from patients infected with genetically diverse HIV-1 from different geographic settings. 10th Conference on Retroviruses and Opportunistic Infections, Boston, 10-14 February 2003. Abstract 669.

29. Sutthent R, Gaudart N, Chokpaibulkit K, Tanliang N, Kanoksinsombath C Chaisilwatana P. p24 antigen detection assay modified with a booster step for diagnosis and monitoring of HIV-1 infection. J Clin Microbiol 2003; 41: 10161022.

30. Nouhin J, Nguyen M, Reynes JM, Henin Y. Evaluation of p24 ultrasensitive assay for the diagnosis of HIV-exposed infants. Abstract WePpB2057. 15th International AIDS Conference, Bangkok, Thailand, 11-16 July 2004.

31. Sherman G, Stevens $G$, Jones S, Horsfield P. Stevens W. Dried blood spots for HIV diagnosis of infants: Improving access to care for HIV affected infants in low resource settings. J AIDS 2006 (in press).

32. De Baets AJ, Edidi BS, Kasali MJ, et al. Pediatric human immunodeficiency virus screening in an african district hospital. Clin Diagn Lab Immunol 2005; 12(1): 86-92.

33. Patton J, Sherman GG, Coovadia AH, Stevens WS, Meyers TM. Ultrasensitive human immunodeficiency virus 1 p24 antigen type assay modified for use on dried whole-blood spots as a reliable, affordable test for infant diagnosis. Clinical and Vaccine Immunology 2006; 13: 152-155.

34. Martin D, Sim J. The laboratory diagnosis of HIV infection. S Afr J Med 2000; 90 105-109.

35. Kuritzkes DR. Clinical application of virus load monitoring and resistance assays. In: Armstrong D, Cohen J, eds. Infectious Disease. London: Harcourt, 1999. 